\title{
THE UTILITY OF SPECTRAL MEASUREMENTS OF SECONDARY REACTIUN PRODUCTS
}

\author{
W.W. HEIDBRINK
}

Plasma Physics Laboratory, Princeton University Princeton, New Jersey, USA

\section{DISCLAIMER}

\begin{abstract}
This report was prepared as an account of work spansored by an agency of the United States Government. Neither lthe Uniled Statts Government nor any agency thefed, nor any of their emplayees, makes any warr anty, express or implied, or assumes any legal liabjlity or respensibility for the aceuracy, completeness, or usefulness of any information, apparatus. preduct, of process diselosed, or represents inat its use would not infringe privately owned rights. Reference herein to any specific commercial product, process, or serwice by trade name, trudertark. manufacturer, or otherwise does not necessarily constitute or imply its endorsement, recommend? $2 n$, or favoring by the United States Government or any agency thereof. The views ard opinions of authors expressed hercin do not necessarily state of reflect those of the United States Gavernment or any agency thascof
\end{abstract}

\begin{abstract}
The spectra of $15 \mathrm{MeV}$ protons and $14 \mathrm{MeV}$ neutrons produced in the burnup of $0.8 \mathrm{MeV}{ }^{3} \mathrm{He}$ ions and $1 \mathrm{MeV}$ tritons through the $d\left({ }^{3} \mathrm{Hc}, \mathrm{p}\right) \alpha$ and $\dot{s}(\mathrm{t}, \mathbf{n}) \alpha$ fusion reactions contan information on the velocity distributions of the energetic ${ }^{3} \mathrm{He}$ ions and tritons.
\end{abstract}


In a magnetically confined deuterium plasma, the behavior of alphalike particles can be studied by measuring the number of $1 \mathrm{MeV}$ tritons and $0.8 \mathrm{MeV}{ }^{3} \mathrm{He}$ ions (produced in the $\mathrm{d}-\mathrm{d}$ fusion reactions) that undergo subsequent $d(t, n) \alpha$ and $d\left({ }^{3} \mathrm{He}, p\right) \alpha$ fusion reactions. "Burnup" measurements of $14 \mathrm{MeV}$ neutrons and of $15 \mathrm{MeV}$ protons have been reported for the PLT $[1,2]$ and PDX tokamaks $[2,3]$ and are in progress on the TFTR [4], JET [5], and Frascati [6] tokamaks. The burnup fluence depends on both the energatic ion confinement and slowing down, while burnup flux measuremeris are particularly useful for studying the rate of slowing down. The purpose of this note is to point out that spectral measurements of the triton and ${ }^{3} \mathrm{He}$ burnup also provide useful information about the behavior of alpha-like particles.

Consider a plasma with moderately low impurity levels $\left(Z_{e f f}\right)$ and election temperature $T_{e}$. The tritons and ${ }^{3} \mathrm{He}$ ions slow down primarily on electrons [7] so pitch-angle scattering of the energetic ions may be neglected. We also assume that the bulk deuterium temperat ure $T_{i}$ is small compared to the $d(t, n) \alpha$ and $d\left({ }^{3} \mathrm{He}, \mathrm{p}\right) \alpha$ resonant energies so that the burnup reartions can be treated as beaur-target reactions. Then the energy distribuion of $14 \mathrm{MeV}$ neutrons or $15 \mathrm{MaV}$ protons $F\left(E_{3}\right)$ is given by [8]

$$
F\left(E_{3}\right)=\frac{1}{2} \int \sin \chi_{1} d \chi_{1} \int d E_{1} \sigma\left(E_{1}\right) E_{1} f_{1}\left(E_{1}\right) \hat{F}\left(E_{3}, E_{1}, \chi_{1}\right),
$$

where $f_{1}\left(E_{1}\right)$ is the triton or ${ }^{3} \mathrm{He}$ energy distribution function, $\sigma$ is the $\mathrm{d}(\mathrm{t}, \mathrm{n}) \alpha$ or $\mathrm{d}\left({ }^{3} \mathrm{He}, \mathrm{p}\right) \alpha$ fusion cross section, and $\hat{F}\left(E_{3}, E_{1}, \chi_{1}\right)$ is the reduced distribution function defined in eq. (7) of Ref. [8]. For fast ions that slow down on electrons, $f_{1}\left(E_{1}\right) \propto E_{1}^{-3 / 2}$. If all of velocity space is confined, the integration over triton or ${ }^{3} \mathrm{He}$ pitch angle $\chi_{1}$ is from $\chi_{1}=0$ to $\chi_{1}=\pi$.

The utility of spectral measurements of the fusion-product burnup is that the spectrum contains information about the velocity-space distribution of the tritons and ${ }^{3} \mathrm{He}$ ions. As an illustration, imagine a vertically 
viewing neutron spectrometer, or a collimated $15 \mathrm{MeV}$ proton detector that measures protons with velocities perpendicular to the magnetic field [9]. If the triton or ${ }^{3} \mathrm{He}$ confinement is isotropic in velocity space, numerical integration of eq. (1) gives the broad neutron and proton spectra shown in Fig. 1. If, however, the velocity space confinement is anisotropic, deviations from this shape are predicted. For example, if a physical mechanism such as ripple losses [10] or fishbones [11] expel energetic ions in the trapped region in velocity space but do not affect the confinement of circulating ions, then more narrow spectra are expected (Fig. 1).

The perpendicular detection geometry illustrated in Fig. 1 is probably the easiest to implement experimentally. Greater sensitivity to energetic ion anisotropy is available with other viewing angles, however. In Fig. 2, this increased sensitivity is illustrated by plotting the contributions to the burnup spectrum from ${ }^{3} \mathrm{He}$ ions in various portions of velocity space for a $15 \mathrm{MeV}$ proton detector that measures protons with pitch angle $\chi_{3}=\pi / 4$. For this detection geometry, the contributions of co-circulating, perpendicular, and counter-circulating ${ }^{3} \mathrm{He}$ ions to the energy spectrum are separated by more than $1 \mathrm{MeV}$.

In summary, collimated spectral measurements of the triton and ${ }^{3} \mathrm{He}$ burnup are useful for detecting possible anisotropies in the velocity-space distributions of these energetic ions.

This work was supported by U.S. Department of Energy Contract No. DE-AC02-76-CHO-3073.

\section{References}

(1] P. Colestock, J.D. Strachan, M. Ulrickson, R. Chrien, Phys. Rev. Lett. 43 (1979) 768.

[2] W.W. Heidbrink, R.E. Chrien, J.D. Strachan, Nucl. Fusion 23 (1983) 
917.

[3] W.W. Heidbrink, Ralph Hay, J.D. Strachan, Phys. Rev. Lett. 53 (1984) 1905.

[4] J.D. Strachan et al., in Proc. of Workshop on Basic Physical Processes of Toroidal Fusion Plasmas, (Varenna, 1985).

[5] G. Sadler et al., Bull. Am. Phys. Soc. 30 (1985) 1585.

66 E. Bittoni et al., Proc. of the Europ. Conf. on Cont. Fusion and Plasma Physics (Budapest, 1985).

17] The condition that the critical energy (for which ion drag equals electron drag) is less than the energy at the peak of the cross section is $T_{e} Z_{e}$ i $\leqslant 30$ for the triton and $T_{e} Z_{\text {eff }} \lesssim 120$ for the ${ }^{3} \mathrm{He}$ ion.

[8] W.W. Heidbrinl:, Nucl. Instrum. Meth. A236 (1985) 380.

[9] W.W. Heidbrink, Nucl. Fusion 24 (1984) 636.

[10] R.J. Goldston, R.B. White, A.H. Boozer, Phys. Rev. Lett. 47 (1981) 647.

(11) K. McGuire et al., Phys. Rev. Lett. 50 (1983) 891. 


\section{Figure Captions}

Fig. 1 (a) Spectrum of perpendicular $14 \mathrm{MeV}$ neutrons $\left(x_{3}=\pi / 2\right)$ produced by $1.0 \mathrm{MeV}$ tritons that slow down on electrons in a cold denterium plasma. The tritons are assumed to populate velocity space uniformly (solid curve); the dashed curve is for a loss cone in the perpendicular part of velocity space $\left(\left|\chi_{1}-\pi / 2\right|<0.63\right)$. (o) Spectrum of perpendicular $15 \mathrm{MeV}$ protons $\left(\chi_{3}=\pi / 2\right)$ produced by $0.8 \mathrm{MeV}^{3} \mathrm{He}$ ions that slow down on electrons in a cold deuterium plasma. The ${ }^{3} \mathrm{He}$ ions are assumed to populate velocity space uniformly (solid curve); the dashed curve is for a loss cone in the perpendicular part of velacity space $\left(\left|\chi_{1}-\pi / 2\right|<0.63\right)$.

Fig. : Spectrum of $15 \mathrm{M} \circ \mathrm{V}$ protons $\left(\chi_{3}=\pi / 4\right)$ produced by $0.8 \mathrm{MeV}$ ${ }^{3} \mathrm{He}$ jons that slow down on electrons in a cold deuterium plasma. The solid curve if ior an isotropic ${ }^{3} \mathrm{He}$ velocity space distribution, the dashed curve is the spectrum produced by co-circulating inns $\left(\chi_{1}<\pi / 4\right)$ and the dotdash curve is the spectrum if only counter-circulating ions $\left(\chi_{1}>3 \pi / 4\right)$ are confined. 

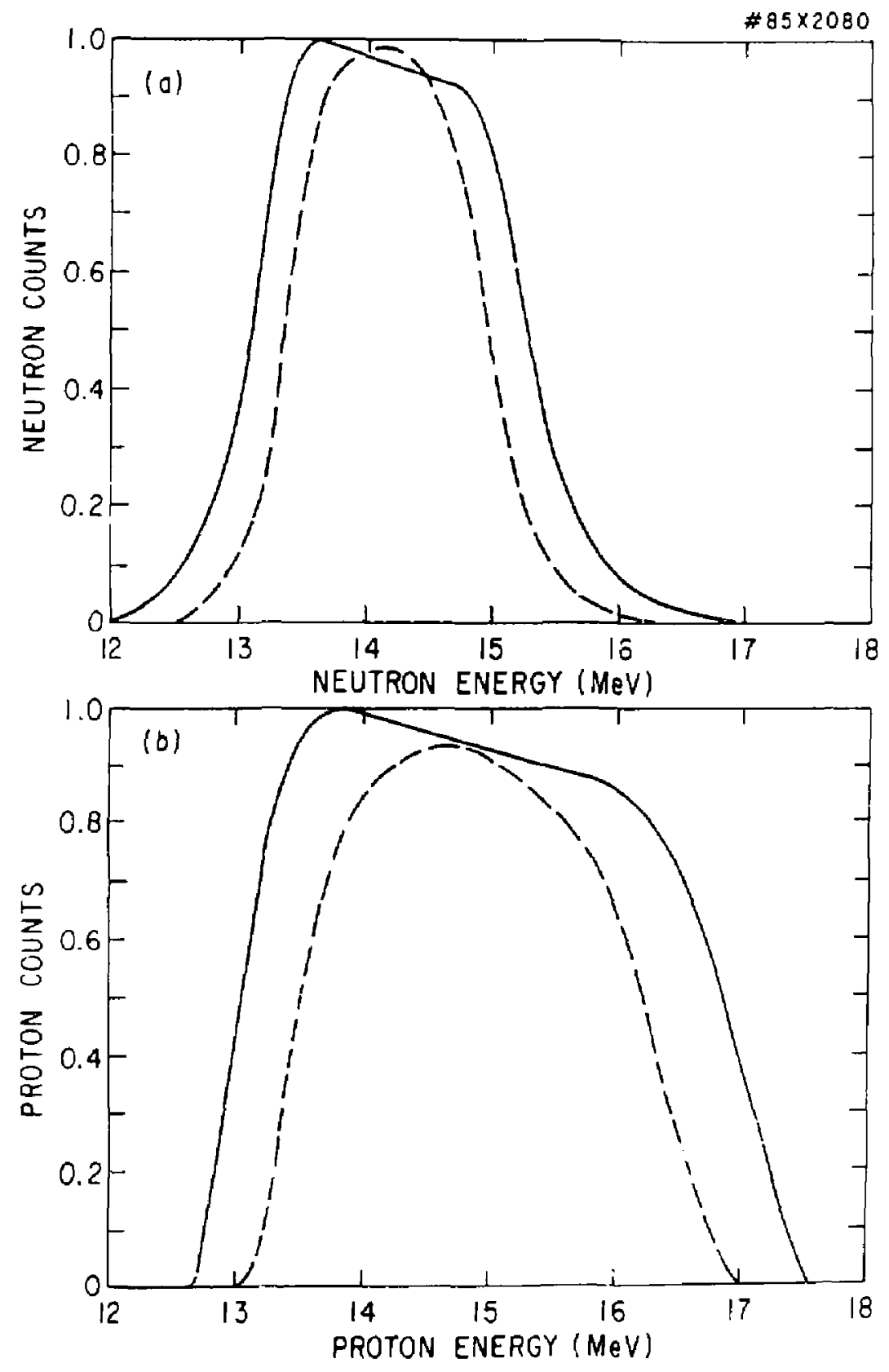

Fig. 1 


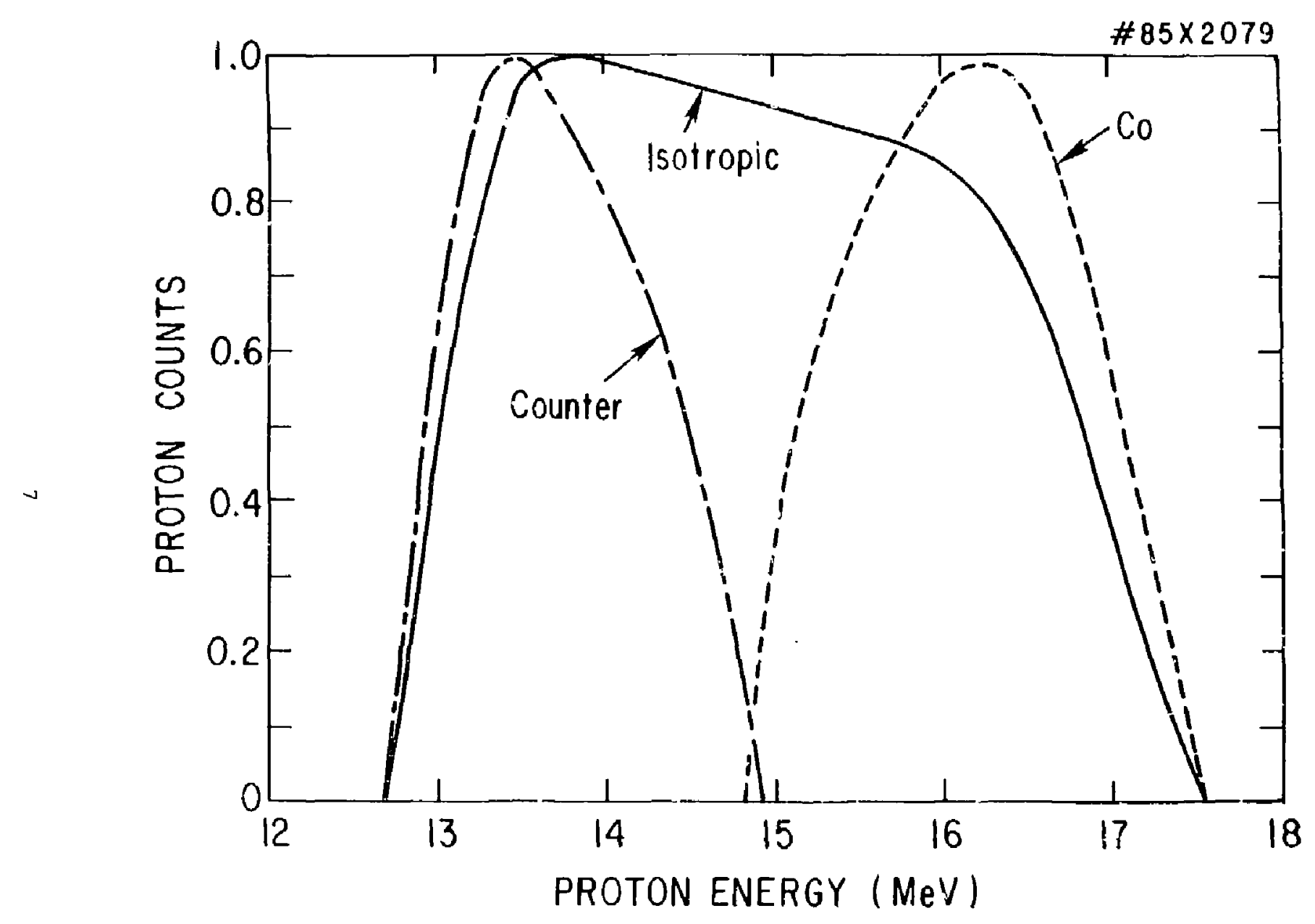

liig. 
Dlasina Res Lab, Auster tac'l Uhiv, ALSTPALTA

x. Fratk J. Paolonit, Uhiv of hollongong, AUSTRATIA

Prof. L.R. Jones, Flinders Uhiv., ALSTRACIA

ETof. M.H. Brennan, Uhiv Sydney, ALSTracta

Prof. $r$. Cap, Inst Theo Phys, AlsiRTa

Prof. Eranie Wethost, Inst thooretische, JELGIUM

Dr. D. Palumbo, Dg XCl Fusion Frog, BEIGIM

Ecole Royale Militaire, Lab de Fhys Plasmas, BeIGTM

DT. P.H. Sakanaka, Chiv Estartual, BRAzII

DF. C.R. Jameg, Uhiv of Albetta, CANRDA

Prof. J. Teidtrenn, Uhiv of untreal, Cantara

Dr. H.M. Skarsyard, Uhiv of Sagkatchesan, ChifazA

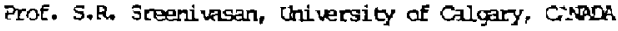

Prof. Tudor it'. Johnston, INRS-Energie, CANARA

Dr, Hannes Enrmad, Uriv Eritish Columbia, Cavan

Or, i.P. Bachynski, MPB Iechnologies, Inc., CANACA

Chalk River, Mel Lab, CANADA

Thengorl Li, SH Inst Fhysics, CIINA

Library, Tsing the Univergity, CrIm

Librarian, Instivute of Etysics, CHinR

Inst Plisma Phys, Acadenia Sinica, CHIn

Dr. Peicer Lukag, Kanenckeho Univ, CabCHOSTOVAKIA

The Wibrian, Qulhen Labaratroy, ExGlyD

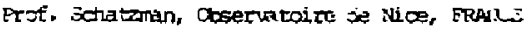

J. Radet, CEt-BP5, ERANCE

AM Jupas Litrary, A: Dupas Library, FRANT

T. Tan Mal, hadery Bibliographic, IONG SON

Preprint library, Cent kes Inst Phys, HUNGRY

Dr. R.K. Chajalani, Wikran Uhiv, DDIA

Dr. B. Drsgupta, Saha Inst, TNDLA

Tr. D. Kaw, Physical Research Lab, INDIA

or. Fillip Rrsenau, Israel Inst Tect, ISPADL

Ecot. S. Oiperman, Jel Aviv thiversity, ISFAE,

Prof. G. Rostagni, Uniy Di Padora, IJALy

Librarian, Int'l It Theo Phys, ILPLY

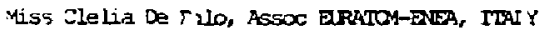

Biblioteca, del CF ERATOA, TWLY

x. H. Yenato, Toshiba Res \& Dev, JAPAN

Jirec. Dept. Lg. Irikamak Dev, JAFRI, IAPAN

Erof. Nobuyulei Inave, Uhiversity of TBKyo, JAPAN

Research Info Center, Nagoja University, JAPAN

Ecof. Kyoji Nishikawa, thiv of itiroshinia, JAPAN

Prof. Slgeru Moti, JABRI, JAPAN

P=of. S. Tanaka, Syoto Uniersity, JPAN

isiorary, Kyoto Universit;", JAFAN

Prot. Ichiro Rawakani, Nition Univ, . TAPAN

Prof. Satoshi Itch, Kyush thiversity, JAPAN

Jr. D.I. Ohoi, Adv. Inst Bei \& Tech, WREA

Tet, Info Division, KAEFI, XCFFA

aibliotineek, Fom-Inst voor Plasta, NETHrilstes

Prof. 5.S. ijley, University of kaikato, NEN ZEALAv

Prof. J.A.C. Cabral, Inst auperior Teon, PCRIUGL
Dr. Octaviar Petrus, ALI IELA Lhiversity, ROMANIA

Prof. M.A. Hellberg, Uhiwersity of Natal, 50 Aftro

Dr. Johan de Villiers, Pla ma Physics, ihseor, so AFrivat fusian Div. Library, JEN, SPATN

Prof. Hans wilhelmson, Galmers univ Teor, SNEvts

Dr. Lennart Stenflo, University of UMEA, JWDDEN

Library, foyal inst Tech, SNEDEN

Centre de Redherchesen, Ecole Polytech Fed, SwrTtprtaks

Dr. V.T. Tolok, Kharkov Fhys Tech Ins, IJSSTR

Dr. D.D. Ryutov, Sioerien Acad Sci, USSR

Dr. G.A. Eliseev, kurchatov Institute, USSR

Or. V.A. Glukhikh, List ELectro-Physical, USSR

Instibute Gen. Fhysics, USSR

Prof. T.J.i, Boyri, Univ College v iales, wAis

ot. Ko Sctindler, Rutre thisersitat, w. GewaN!

Mrelear Res Estao, Julich Ltod, W. GPMANY

i.jorazian, Max-Plande Instiede, $H$, GEMMNY

Bibliothex, Inse plasmaforsching, w. GMMANY

Prof. R.K. Janew, Ins o Pys, vujuszavis 